\title{
Oligodendrocytes damage in Alzheimer's disease: Beta amyloid toxicity and inflammation
}

\author{
ALEJANDRO D. ROTH, ${ }^{1,2}$ GIGLIOLA RAMÍREZ, ${ }^{1}$ RODRIGO ALARCÓN ${ }^{1}$ \\ and ROMMY VON BERNHARDI ${ }^{1}$
}

1. Laboratory Neuroscience, Department of Neurology, Faculty of Medicine, Pontificia Universidad Católica de Chile, Santiago, Chile. 2. Brain Tumor Research Centre, Montreal Neurological Institute, McGill University, Montréal, Quebec, Canada

\begin{abstract}
Research on Alzheimer's disease (AD) focuses mainly on neuronal death and synaptic impairment induced by $\beta$-Amyloid peptide $(A \beta)$, events at least partially mediated by astrocyte and microglia activation. However, substantial white matter damage and its consequences on brain function warrant the study of oligodendrocytes participation in the pathogenesis and progression of AD. Here, we analyze reports on oligodendrocytes' compromise in AD and discuss some experimental data indicative of A $\beta$ toxicity in culture. We observed that $1 \mu \mathrm{M}$ of fibrilogenic $\mathrm{A} \beta$ peptide damages oligodendrocytes in vitro; while pro-inflammatory molecules ( $1 \mu \mathrm{g} /$ $\mathrm{ml} \mathrm{LPS}+1 \mathrm{ng} / \mathrm{ml} \mathrm{IFN} \gamma$ ) or the presence of astrocytes reduced the A $\beta$-induced damage. This agrees with our previous results showing an astrocyte-mediated protective effect over A $\beta$-induced damage on hippocampal cells and modulation of the activation of microglial cells in culture. Oligodendrocytes protection by astrocytes could be, either by reduction of $A \beta$ fibrilogenesis/deposition or prevention of oxidative damage. Likewise, the decrease of $A \beta$-induced damage by proinflammatory molecules could reflect the production of trophic factors by activated oligodendrocytes and/or a metabolic activation as observed during myelination. Considering the association of inflammation with neurodegenerative diseases, oligodendrocytes impairment in AD patients could potentiate cell damage under pathological conditions.
\end{abstract}

Key terms: cell death, glial cells, pro-inflammatory cytokines.

One of the major histopathological characteristics of Alzheimer's disease (AD) is the presence of senile plaques (SP), composed mainly of Amyloid $\beta$ peptide $(\mathrm{A} \beta)$ aggregates and activated microglia at the center, surrounded by a crown of activated astrocytes. Glial activation results in the sustained production of proinflammatory molecules, giving rise to a chronic inflammatory process. Research on AD has focused mostly on the generation of $A \beta$ peptide and its induction of neuronal damage (see review by Selkoe, 2004; Cerpa et al., 2003; Lorenzo, 2004), while the importance of astrocyte and microglial activation induced by $A \beta$ has gained recognition in the last few years (von Bernhardi and Ramírez, 2001; von Bernhardi and Eugenín, 2004). However, although oligodendrocytes (OLGs) are in intimate contact and are key for the morphofunctional maintenance of neurons, there is little information about $A \beta$ cytotoxicity on OLGs.

\section{WHITE MATTER DAMAGE AND \\ OLIGODENDROCYTES PATHOLOGY IN \\ ALZHEIMER'S DISEASE}

The presence of white matter lesions (WML) and myelin abnormalities in the brain of AD patients is well supported by cytopathological (Braak et al., 2000; de la Monte, 1989; Englund et al., 1988; Kobayashi et al., 2002), neurochemical (Malone and Szoke, 1985; Roher et al., 2002; Sevennerholm and Gottfries, 1994),

Corresponding author: Rommy von Bernhardi, Laboratory Neuroscience, Department of Neurology, Faculty of Medicine, Pontificia Universidad Católica de Chile, Marcoleta 391, Santiago, Chile, Tel.: (56-2) 354-6936, Fax: (56-2) 632-1924, Email: rvonb@med.puc.cl 
electrophysiological (Tanaka et al., 1994) and live imaging techniques (Bartzokis et al., 2003, 2004; de Leeuw et al., 2004). While WML are a hallmark of cerebrovascular pathology, evidence suggest that they are also related to AD (Brown et al., 2000; Vermeer et al., 2003; Decarli, 2004), particularly, the correlation between WML and hippocampal atrophy in AD patients (de Leeuw et al., 2004) and their effect on cognition decay (Decarli, 2004), which could reflect $A \beta$ deposition around blood vessel walls and subsequent ischemia (Iwatsubo et al., 1994), a situation to which OLGs are particularly vulnerable (review by Volpe, 1998). Whereas it is still unknown whether OLG damage is part of the $\mathrm{AD}$ pathogenesis or a consequence of other pathological processes, it has been proposed that differences in myelination onset (Braak and Braak, 1996; Power et al., 2002) can increase the susceptibility for myelin breakdown and subsequent axonal dysfunction, a process observed during aging (Nielsen and Peters, 2000) and exacerbated in AD (Bartzokis et al., 2004). A decrease of OLGs would have a profound effect on neuronal function and viability, since OLGs provide trophic and metabolic support for neurons and axons ( $\mathrm{Du}$ and Dreyfuss, 2002; Dai et al., 2003; Court and Alvarez, 2005).

An unsolved point is whether myelin loss would be secondary to neuronal death and the subsequent axonal degeneration, resulting in the white matter patterns detected by imaging (Noble, 2004). While myelin damage can result from axonal degeneration, it also is induced by several insults (Bartzokis, 2004), including $\mathrm{A} \beta$ (Curtain et al., 2001; Kiuru et al., 1999) and radical oxygen species (ROS) (Whitman and Cotman, 2004). Myelin abnormalities described in $A D$ are observed in the absence of evident of axonal damage (Umahara et al., 2002; Bartzokis et al., 2003) and are similar to the defects in the formation of myelin sheaths observed in aging individuals (Nielsen and Peters, 2000). The neurons first affected by AD are those that are myelinated at the latest periods of life (Braak and Braak, 1996). It has been suggested that the death of myelinating OLGs would be a critical initiating step of AD (Bartzokis et al., 2004).

\section{OLIGODENDROCYTES DEATH INDUCED BY AB}

High levels of $A \beta$ are observed in the white matter of AD patients (Roher et al., 2002; Wiesniewski et al., 1989), and as mentioned above, $A \beta$ aggregates are considered responsible for the neuronal and vascular degeneration in AD brains (Yankner et al., 1989; Thomas et al., 1996). Although the molecular mechanism of $A \beta$-mediated cell death is not clearly defined, it is known that it probably involves oxidative stress, a situation to which OLGs are particularly susceptible because their reduced glutathione (GSH) content is low and they have a high concentration of iron, thus presenting an impaired ability to scavenge oxygen radicals (Back et al., 1998; Juurlink et al., 1998). Furthermore, A $\beta$ possesses an increased capability for damaging cholesterol rich membranes, such as those found in OLGs and myelin (Subasinghe et al., 2003).

$A \beta$ toxicity on OLGs has been assayed using the $A \beta$ fragments that span amino acids 1 through $40\left(\mathrm{~A} \beta_{1-40}\right)$ or 25 through $35\left(\mathrm{~A} \beta_{25-35}\right)$, but there are no reports using the full and most amyloidogenic $A \beta$ peptide $\left(\mathrm{A} \beta_{1-42}\right)$. A $\beta$-induced OLG death presents characteristic features of apoptosis (Xu et al., 2001), mediated through the activation of the nSMase-ceramide cascade (Lee et al., 2004). It possibly involves TNF $\alpha$, neurotrophin receptor p75, and Fas ligand and causes mitochondrial dysfunction and oxidative stress in vitro (Xu et al., 1998) and in vivo after stereotaxic injection of $A \beta$ (Jantaratnotai et al., 2003). $A \beta_{1-40}$ and $A \beta_{25}$ 35 are cytotoxic to oligodendrocytes expressing intermediate differentiation markers (Xu et al., 2001), and $\mathrm{A} \beta_{25-35}$ toxicity has been assayed on mature OLGs (Lee et al., 2004). Maximal cytotoxic effects were observed at peptide concentrations above $20 \mu \mathrm{M}$.

We studied the cytotoxicity of $A \beta_{1-42}$ on OLGs obtained from neonatal rat brain cultures that exhibited the characteristic 
morphology of the oligodendroglial cell linage, large cell bodies with multiple branching processes and lamellipodia (Fig 1A) and expressed OLGs-specific markers galactocerebroside (GalC), cyclic nucleotide 3'-phosphodiesterase (CNPase), and the OLG mature state marker: Myelin Basic Protein (MBP, Fig 1A). Exposure of OLG cell cultures to $1 \mu \mathrm{M}$ of $\mathrm{A} \beta_{1-42}$ induced: cell death, as evidenced by a $40 \%$ decrease of MTT reduction activity (MTT, Fig 1B); morphological changes suggestive of damage, such as the breakdown of OLGs processes and appearance of shrunken cell bodies (Fig $2 \mathrm{~A}$ ); and an 3.2-fold increase of lactate dehydrogenase activity released to the culture media (LDH; Fig 2B). The $\mathrm{A} \beta_{1-42}$ concentrations used were 10 to 30 times lower than those reported for $A \beta_{1-40}$ and $\mathrm{A} \beta_{25-35}$ (Xu et al., 2001; Lee et al., 2004). This higher toxicity could reflect a higher sensitivity of mature oligodendrocytes to $\mathrm{A} \beta$, compared to that of immature cells, or alternatively it could depend at least partially on the stronger amyloidogenic and fibrilogenic properties of $A \beta_{1-42}$ (Riek et al., 2001), which we used in these experiments.

OLG damage by $A \beta_{1-42}$ was decreased in cultures containing astrocytes (Fig 1B). This preservation of the MTT reduction could result through the lowering of $A \beta_{1-42}$ damage effectors, such as ROS, in agreement with the high level of antioxidants (Wilson, 1997) and detoxification enzymes present in astrocytes (reviewed by Minn et al., 1991).

In OLGs exposed simultaneously to $\mathrm{A} \beta_{1-42}$ and proinflammatory molecules (LI), cell death was reduced by nearly $50 \%$, although it remained significantly higher than that observed under control conditions $(p=0.0038)$. We have observed previously that proinflammatory molecules protect hippocampal neurons from $A \beta_{1-42}$ neurotoxicity (Ramírez et al., 2005), an effect that depended on the presence of astrocytes or its conditioned media (von Bernhardi and Eugenín, 2004; Ramírez et al., 2005), which appears to be mediated by TGF $\beta 1$ (Herrera-Molina and von Bernhardi, 2005; Ramírez et al., 2005). The OLG protection by LI was not dependent on the presence of astrocytes, but might result from OLGs ability to release trophic molecules when stimulated (Dai et al., 2003; Du and Dreyfuss, 2002). While our results contradict the mainstream notion that proinflammatory molecules necessarily contribute to the progression of myelin and OLG damage (Merrill et al., 1993; Smith et al., 1999; Xie et al., 2002; Popovic et al., 2002), we propose that low levels of inflammation may prime a subpopulation of cells, activating certain cell signaling pathways (Leyton and Quest, 2004) and modifying calcium homeostasis (Campanella et al., 2004), allowing them to resist a certain degree of injury. In that sense, whereas we cannot provide a definitive explanation, we propose that a factor that could explain the contradiction could be the maturity of our OLGs. It has been shown that low concentrations of $\mathrm{TNF} \alpha$ alter differentiation rather than cell survival (Cammer, 2000), a situation which could allow OLGs to activate ROS damagereducing systems, such as the increase of peroxisomal enzymes during myelination (Lazo et al., 1991). Our results also suggest that an aggressive inhibition of glial inflammatory responses to $A \beta$ may not result in decreased oligodendrocytes and neuronal damage as previously thought.

\section{RECAPITULATION}

1. Treatment of mature oligodendrocytes with $1 \mu \mathrm{M} \mathrm{A} \beta_{1-42}$ resulted in mature OLGs death as measured by a decrease of MTT reduction and an increase of LDH release.

2 . The cytotoxic effect of $A \beta_{1-42}$ on oligodendrocytes was prevented by coculture with astrocytes and by the presence of pro-inflammatory molecules (LPS and IFN- $\gamma$ ), although regressive morphological changes suggesting damage persisted.

3. The functions served by oligodendrocytes suggest that, even if myelin damage on AD was secondary (e.g. to neuronal death), the loss of the trophic support they provide could lead to an increased vulnerability of neurons, increased inflammation, and further cell damage. 

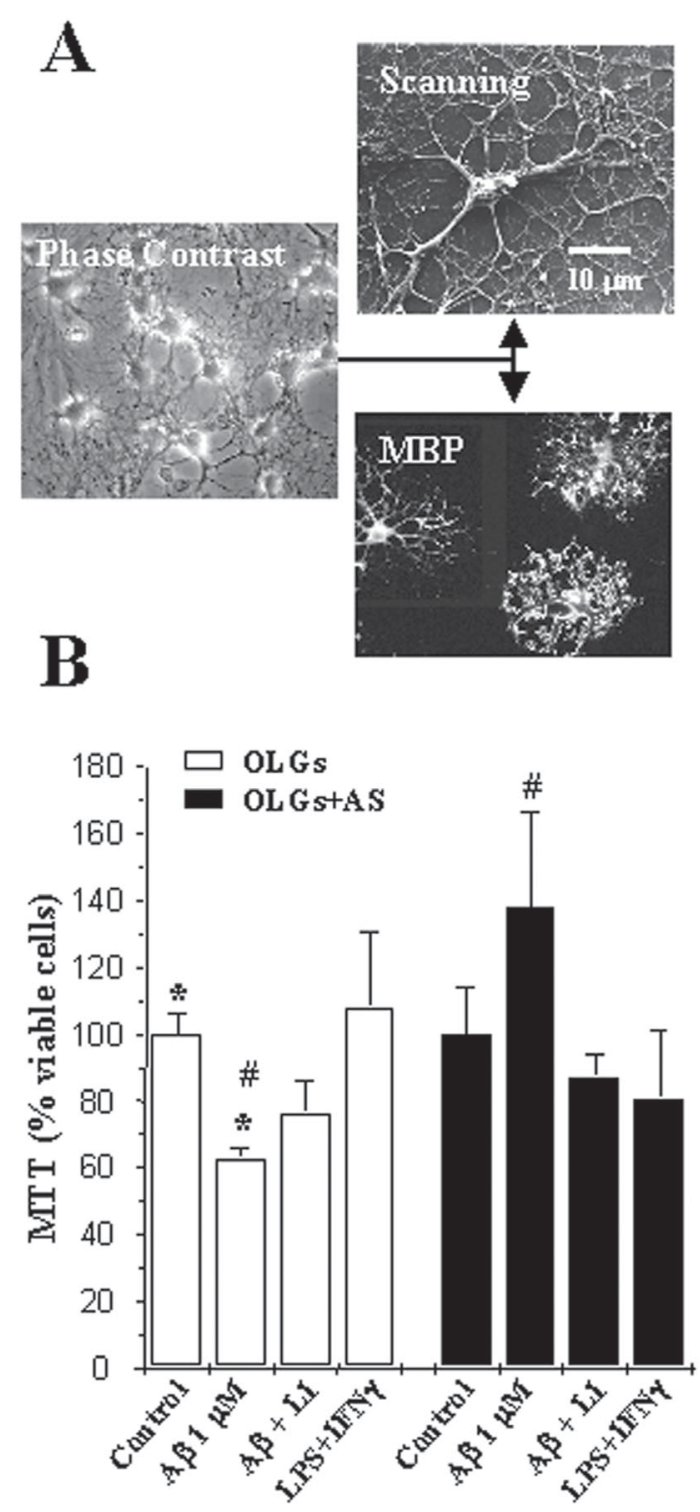

Figure 1. A. Characterization of mature differentiated oligodendrocytes. OLGs cultures were established according to McCarthy and de Vellis (1980), in the presence of chemically defined medium (without serum) as described by Nobel and Mayer-Pröschel (1998). Phase contrast and scanning electron microscopy of mature OLGs with characteristic branching cell processes. Immunocytocheminal labeling of OLGs cultures with an antibody against MBP (1/400 MAB386, Chemicon International) as marker for mature OLGs showing intense MBP immunoreactivity.

B. Cell viability measured by the MTT assay: A $\beta$ decreases the reduction metabolism of OLGs. Reduction activity of oligodendrocytes (OLGs) and oligodendrocytes plus astrocytes (OLGs+AS). Cell cultures were treated with $1 \mu \mathrm{M} \mathrm{A} \beta(\mathbf{A} \boldsymbol{\beta}), 1 \mu \mathrm{g} / \mathrm{ml} \mathrm{LPS}+10 \mathrm{ng} / \mathrm{ml} \mathrm{IFN}-\gamma(\mathbf{L I})$, or A $\beta+\mathrm{LI}$ for 24 hr. A $\beta$ decreased MTT reduction, but its effect was reduced when OLGs were co-cultured with astrocytes. Values correspond to the mean \pm SEM from cell cultures exposed to 2 different preparations of fibrillar $A \beta$, in triplicate, with similar results. Differences in the percentage of apoptotic cells and reduction activity of OLGs cultures were evaluated with a Kruskal Wallis H-oneway ANOVA Test $(\mathrm{p}=0.035)$. Once significant differences in the variance analysis were established, the different conditions were evaluated with a Wilcoxon Rank Sum/Mann-Whitney U-Test. * shows significant differences $(\mathrm{p}=0.0026)$ between $\mathrm{A} \beta$ with respect to control cultures. \# shows a significant difference $(\mathrm{p}<0.008)$ for the cultures exposed to $A \beta$ with and without astrocytes. 

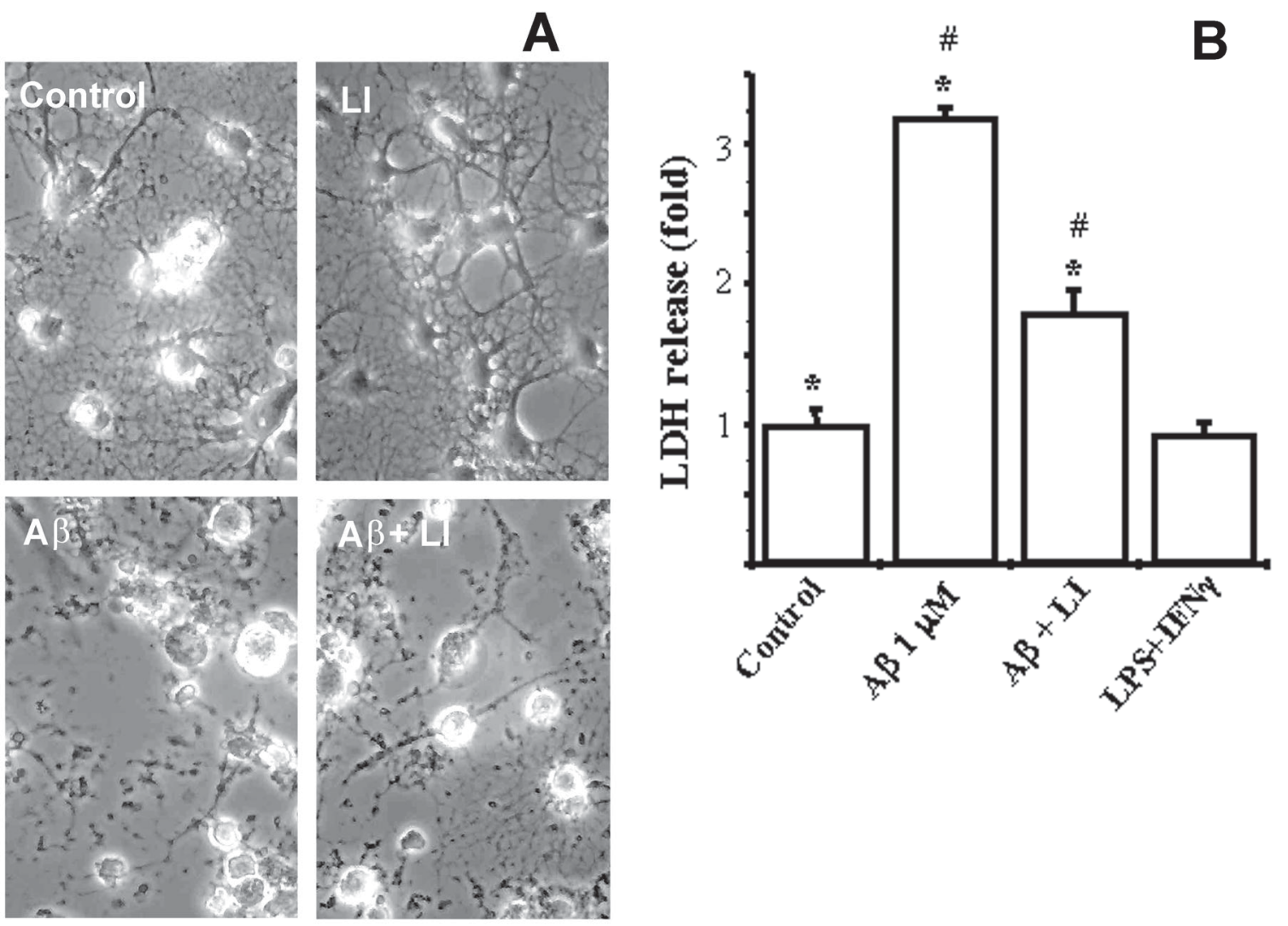

Figure 2. Morphological changes and cell death induced in OLGs by $A \beta$.

A. Phase contrast microscopy of OLGs cultures exposed to $1 \mu \mathrm{M}$ of $\mathrm{A} \beta_{1-42}(\mathrm{~A} \beta), 1 \mu \mathrm{g} / \mathrm{ml} \mathrm{LPS}+10$ $\mathrm{ng} / \mathrm{ml} \mathrm{IFN}-\gamma(\mathrm{LI})$ or $\mathrm{LI}+\mathrm{A} \beta$ for $24 \mathrm{~h}$. Note that, although cell death in cultures treated with LI+A $\beta$ was reduced by $40 \%$ compared to OLGs exposed to A $\beta$ (see panel B), profound morphological alterations remain. B. Cell death determined by the LDH assay in cultures exposed to the same conditions as in panel A. Results correspond to 3 independent OLGs cultures performed in triplicate. Error bars represent SEM. Differences in the LDH release were evaluated with a one-way ANOVA with a Kruskal Wallis H-Test $(\mathrm{p}<0.001)$. After determination of significant differences in the variance analysis, the different conditions were evaluated with a Wilcoxon Rank Sum/MannWhitney U-Test. * shows significant differences between cultures exposed to $A \beta(\mathrm{p}<0.0001)$ and to $\mathrm{A} \beta+\mathrm{LI}(\mathrm{p}<0.0038)$ with respect to control cultures. \# shows significant differences between OLGs exposed to $A \beta+L I(p<0.0027)$ with respect to those exposed to $A \beta$.

\section{ACKNOWLEDGEMENTS}

This article is dedicated to Dr. Patricio Zapata, an outstanding mentor, who has both contributed in the formation of several generations of Chilean scientists and inspired many generations of medical students with his neurophysiology course.

This work was supported by the grant 1040831 from FONDECYT to RvB.

\section{REFERENCES}

BACK SA, GAN X, LI Y, ROSEMBERG PA, VOLPE JJ (1998) Maturation-dependent vulnerability of oligodendrocytes to oxidative stress-induced death caused by glutathione depletion. J Neurosci 18: 6241-6253

BARTZOKIS G, CUMMINGS JL, SULTZER D, ENDERSON VW, NEUCHTERLEIN KH, MINTZ J (2003) White matter structural integrity in healthy aging adults and patients with Alzheimer's disease: A magnetic resonance imaging study. Arch Neurol 60: 393-398 
BARTZOKIS G (2004) Age-related myelin breakdown: A developmental model of cognitive decline and Alzheimer's disease. Neurobiol Aging 25: 5-18

BARTZOKIS G, SULTZER D, LU PH, NEUCHTERLEIN KH, MINTZ J CUMMINGS JL (2004) Heterogeneous age-related breakdown of white matter structural integrity: Implications for cortical "disconnection" in aging and Alzheimer's disease. Neurobiol Aging 25: 843-851

BRAAK H, BRAAK E (1996) Development of Alzheimerrelated neurofibrillary changes in the neocortex inversely recapitulates cortical myelogenesis. Acta Neuropathol (Berl) 92: 197-201

BRAAK H, DEL TREDICI K, SCHULTZ C, BRAAK E (2000) Vulnerability of select neuronal types to Alzheimer's disease. Ann NY Acad Sci 924: 53-61

BROWN WR, MOODY DM, THORE CR, CHALLA VR (2000) Cerebrovascular pathology in Alzheimer's disease and leukoaraiosis. Ann NY Acad Sci 903: 3945

CAMMER W (2000) Effects of TNF $\alpha$ on immature and mature oligodendrocytes and their progenitors in vitro. Brain Research 864: 213-219

CAMPANELLA M, PINTON P, RIZZUTO R (2004) Mitochondrial $\mathrm{Ca}^{+2}$ homeostasis in health and disease. Biol Res 37: 653-660

CERPA WF, BARRÍA MI, CHACÓN M, SUAZO M, GONZALEZ M, INESTROSA NC (2003) APP $135-156$ modulates copper induced neurotoxicity in vivo. Memory, morphology, oxidative stress and uptake of copper. Biol Res 36: R-31

COURT F, ÁLVAREZ J (2005) Local regulation of the axonal phenotype, a case of merotrophism. Biol Res 38: $365-374$

CURTAIN CC, ALI F, VOLITAKIS I, CHERRY RA, NORTON RS, BEYREUTHER K, BARROW CJ, MASTERS CL, BUSH AI, BARNHAM KJ (2001) Alzheimer's disease amyloid-beta binds copper and zinc to generate an allosterically ordered membranepenetrating structure containing superoxide dismutaselike subunits. J Biol Chem 276: 20466-20473

DAI $X$, LERCHER LD, CLINTON PM, DU $Y$, LIVINGSTON D, VIEIRA C, YANG L, SHEN MM, DREYFUS CF (2003) Trophic role of oligodendrocytes in the basal forebrain. J Neurosci 23: 5846-5853

DECARLI C (2004) Vascular factors in dementia: An overview. J Neurol Sci. 226: 19-23

DE LA MONTE SM (1989) Quantitation of cerebral atrophy in preclinical and end-stage Alzheimer's disease. Ann Neurol 25: 450-459

DE LEEUW F-E, BARKHOF F, SCHELTENS P (2004) White matter lesions and hippocampal atrophy in Alzheimer's disease. Neurology 62: 310-312

DU YL, DREYFUSS CF (2002) Oligodendrocytes as providers of growth factors. J Neurosci Res 68: 647654

ENGLUND E, BRUN A, AILING C (1988) White matter changes in dementia of Alzheimer's type. Brain 111: $1425-1439$

HERRERA-MOLINA R, VON BERNHARDI R (2005) Transforming growth factor- $\beta 1$ produced by hippocampal cells modulates microglial reactivity in culture. Neurobiol Disease 19: 229-236

IWATSUBO T, ODAKA A, SUZUKI N, MIZUSAWA H, NUKINA N, IHARA Y (1994) Visualization of A beta 42(43) and A beta 40 in senile plaques with endspecific Abeta monoclonals: Evidence that an initially deposited species is A beta 42 (43). Neuron 13: 45-53

JANTARATNOTAI N, RYU JK, KIM SU, MCLARNON JG (2003) Amyloid $\beta$ peptide-induced corpus callosum damage and glial activation in vivo. NeuroReport 14 : 1429-1433

JUURLINK BH, THORBURNE SK, HERTZ L (1998) Peroxide-scavenging deficit underlies oligodendrocytes susceptibility to oxidative stress. Glia 22: $371-378$

KIURU S, SALONEN O, HALTIA M (1999) Gelsolinrelated spinal and cerebral amyloid angiopathy. Ann Neurol 45: 305-311

KOBAYASHI K, HAYASHI M, NAKANO H, FUKUTANI Y, SASAKI K, SHIMAZAKI M, KOSHINO Y (2002) Apoptosis of astrocytes with enhanced lysosomal activity and oligodendrocytes in white matter lesions in Alzheimer's disease. Neuropathol Appl Neurobiol 28: 238-251

LAZO O, SINGH AK, SINGH I (1991) Postnatal development and isolation of peroxisomes from brain. $\mathrm{J}$ Neurochem 56: 1343-53

LEE J-T, XU J, LEE J-M, KU G, HAN X, YANG D-I, CHEN S, HSU CY (2004) Amyloid- $\beta$ peptide induces oligodendrocytes death by activating the neutral sphingomyelinase-ceramide pathway. J Cell Biol 164: $123-131$

LEYTON L, QUEST AF (2004) Supramolecular complex formation in cell signaling and disease: An update on a current theme in cell life and death. Biol Res 37: 29-43

LORENZO A (2004) The neuronal dystrophy induced by the amyloid- $\beta$-peptide $(A \beta)$ and its modulator agents. Biol Res 37: R-12

MCCARTHY KD, DE VELLIS J (1980) Preparation of separate astroglial and oligodendroglial cell cultures from rat cerebral tissue. J Cell Biol 85: 890-902

MALONE MJ, SZOKE MC (1985) Neurochemical changes in white matter. Aged human brain and Alzheimer's disease. Arch Neurol 42: 1063-1066

MERRILL JE, IGNARRO LJ, SHERMAN MP, MELINEK J, LANE TE (1993) Microglial cell cytotoxicity of oligodendrocytes is mediated through nitric oxide. J Immunol 151: 2132-2141

MINN A, GHERSI-EGEA JF, PERRIN R, LEININGER B, SIEST G (1991) Drug metabolizing enzymes in the brain and cerebral micro vessels. Brain Res Brain Res Rev 16: 65-82

NIELSEN K, PETERS A (2000) The effects of aging on the frequency of nerve fibers in rhesus monkey striate cortex. Neurobiol Aging 21: 621-628

NOBLE M (2004) The possible role of myelin destruction as a precipitating event in Alzheimer's disease. Neurobiol Aging 25: 25-31

NOBLE M, MAYER-PRÖSCHEL M (1998) Culture of astrocytes, oligodendrocytes and O-2 progenitor cells. In: BANKER G, GOSLIN K (ed) Culturing Nerve Cells . Cambridge, London: Bradford Book. pp: 499-544

POPOVIC N, SCHUBART A, GOETZ BD, ZHANG SC, LININGTON C, DUNCAN ID (2002) Inhibition of autoimmune encephalomyelitis by a tetracycline. Ann Neurol 51: 215-223

POWER J, MAYER-PROSCHEL M, SMITH J, NOBLE M (2002) Oligodendrocytes precursor cells from different brain regions express divergent properties consistent with the differing time courses of myelination in these regions. Dev Biol 245: 362-375

RAMÍREZ G, TORO R, DÖBELI H, VON BERNHARDI $R$ (2005) Protection of rat primary hippocampal cultures from $A \beta$ cytotoxicity by pro-inflammatory molecules is mediated by astrocytes. Neurobiol Disease 19: $243-254$

RIEK R, GUNTERT P, DOBELI H, WIPF B, WUTHRICH K (2001) NMR studies in aqueous solution fail to identify significant conformational differences between the monomeric forms of two Alzheimer peptides with 
widely different plaque-competence, A beta(1-40)(ox) and A beta(1-42)(ox). Eur J Biochem 268: 5930-6

ROHER AE, WEISS N, KOKJOHN TA, KUO YM, KALBACK W, ANTHONY J, WATSON D, LUEHRS DC, SUE L, WALKER D, EMMERLING M, GOUX W, BEACH T (2002) Increased A beta peptides and reduced cholesterol and myelin proteins characterize white matter degeneration in Alzheimer's disease. Biochemistry 41: 11080-11090

SELKOE DJ (2004) Cell biology of protein misfolding: The examples of Alzheimer's and Parkinson's diseases. Nat Cell Biol 6: 1054-61

SEVENNERHOLM L, GOTTFRIES CG (1994) Membrane lipids, selectively diminished in Alzheimer brains, suggests synapse loss as a primary event in early-onset form (type I) and demyelination in later-onset from (type II). J Neurochem 62: 1039-1047

SMITH KJ, KAPOOR R, FELTS PA (1999) Demyelination: The role of reactive oxygen and nitrogen species. Brain Pathol 9: 69-92

SUBASINGHE S, UNABIA S, BARROW CJ, MOK SS, AGUILAR MI, SMALL DH (2003) Cholesterol is necessary both for the toxic effect of Abeta peptides on vascular smooth muscle cells and for Abeta binding to vascular smooth muscle cell membranes. J Neurochem 84: 471-9

TANAKA F, KACHI T, YAMADA T, SOBUE G (1994) Auditory and visual event-related potentials and flash visual evoked potentials in Alzheimer's disease: Correlations with Mini-Mental State examination and Raven's coloured progressive matrices. J Neurol Sci 156: 83-88

THOMAS T, THOMAS G, MCLENDON C, SYTTON T, MULLAN M (1996) Beta-amyloid-mediated vasoactivity and vascular endothelial damage. Nature 380: 168-171

UMAHARA T, TSUCHIYA K, IKEDA K, KANAYA K, IWAMOTO T, TAKASAKI M, MUKAI K, SHIBATA N, KATO S (2002) Demonstration and distribution of tau-positive glial coiled body-like structures in white matter and white matter threads in early onset Alzheimer's disease. Neuropathology 22: 9-12
VERMEER SE, PRINS ND, DEN HEIJER T, HOFMAN A, KOUDSTAAL PJ, BRETELER MMB (2003) Silent brain infarcts and the risk of dementia and cognitive decline. N England J Med 348: 1215-1222

VOLPE JJ (1998) Brain injury in the premature infant: Overview of clinical aspects, neuropathology, and pathogenesis. Semin Pediatr Neurol 5: 135-151

VON BERNHARDI R, RAMÍREZ G (2001) Microgliaastrocyte interaction in Alzheimer's disease: Friends or foes for the nervous system? Biol Res 34: 123-128

VON BERNHARDI R, EUGENÍN J (2004) Microglial reactivity to $A \beta$ is modulated by astrocytes and proinflammatory factors. Brain Res 1025: 186-193

WIESNIEWSKI HM, BANCHER C, BARCIKOWSKA M, WEN GY, CURRIE J (1989) Spectrum of morphological appearance of amyloid deposits in Alzheimer's disease. Acta Neuropathol (Berl) 78: 337 347

WILSON JX (1997) Antioxidant defense of the brain: A role for astrocytes. Can J Physiol Pharmacol 75: 114963

WHITMAN GT, COTMAN CW (2004) Oligodendrocyte degeneration in AD. Neurobiol Aging 25: 33-6

XIE Z, WIE M, MORGAN TE, FABRIZIO P, HAN D, FINCH CE, LONGO VD (2002) Peroxynitrite mediates neurotoxicity of amyloid beta-peptide 1-42- and lipopolysaccharide-activated microglia. J Neurosci 22: 3484-3492

XU J, YEH CH. YEN S, HE L, SENSI SL, CANZONIERO LM, CHOI DW, HSU CY (1998) Involvement of de novo ceramide biosynthesis in tumor necrosis factoralpha/cycloheximide-induced cerebral endothelium cell death. J Biol Chem 273: 16521-16526

XU J, CHEN S, AHMED SH, CHEN $\mathrm{H}$, KU $\mathrm{G}$, GOLDBERG MP, HSU CY (2001) Amyloid-b peptides are cytotoxic to oligodendrocytes. J Neurosci 21: $\mathrm{RC} 118(1-5)$

YANKNER BA, DAWES LR, FISHER S, VILLAKOMAROFF I, OSTER-GRANITE ML, NEVE RI (1989) Neurotoxicity of a fragment of the amyloid precursor associated with Alzheimer's disease. Science 245: 417-420 